\title{
Modulations in seed micromorphology reveal signature of adaptive species-diversification in Dendrobium (Orchidaceae)
}

\author{
Bhupendra Chaudhary $^{1^{*}}$, Pritam Chattopadhyay $^{2}$, Nirmalya Banerjee $^{2}$ \\ ${ }^{1}$ School of Biotechnology, Gautam Buddha University, Greater Noida, India; *Corresponding Author: bhupendrach@gmail.com \\ ${ }^{2}$ Department of Botany, Visva-Bharati University, Santiniketan, India
}

Received 30 November 2013; revised 30 December 2013; accepted 7 January 2014

Copyright (C 2014 Bhupendra Chaudhary et al. This is an open access article distributed under the Creative Commons Attribution License, which permits unrestricted use, distribution, and reproduction in any medium, provided the original work is properly cited. In accordance of the Creative Commons Attribution License all Copyrights (c) 2014 are reserved for SCIRP and the owner of the intellectual property Bhupendra Chaudhary et al. All Copyright (C) 2014 are guarded by law and by SCIRP as a guardian.

\section{ABSTRACT}

During speciation in flowering plants, many morphological characters were evolved in response to continuous selection pressure. Such characters are largely governed by genetic changes or get modulated according to ecological adaptations. To explore the potential of latter, a novel comparative analysis of seed micromorphology and ultrastructure was performed in twenty species in the genus Dendrobium (Orchidaceae) from well-defined altitude based phytogeographical realms i.e. temperate, subtropical and tropical regions. Seed morphological characteristics from all collected species were examined using 13 quantitative traits descriptors. Comparative seed morphology revealed that the species from temperate region have larger seed volumes and seed volumelembryo volume ratio than species from subtropical or tropical regions irrespective of their phylogenetic association. Hence, phylogenetically related species emphasized their preference for a climatic region as their prime habitat. Similar trends towards gradual increase of percentage free air space were observed in the species of tropical to subtropical and subtropical to temperate regions. The higher percentage of free air space may have an advantage for the species from temperate region with relatively low atmospheric pressure that had greater buoyancy for optimal seed dispersal. Also, phylogenetically distant species from a particular climatic region, showed characteristic features of the testa cell walls sculptured with bead-like orna- mentations or covered with cottony white substances. Based on these observations, it may be concluded that seed volume, \% free air space and seed coat ornamentation in Dendrobium species are signatures of adaptation according to climatic preferences rather than their selection during speciation.

\section{KEYWORDS}

Dendrobium; Seed Micromorphology; Phytogeography; Tropical; Subtropical; Temperate; Phylogeny

\section{INTRODUCTION}

In the evolutionary history of any organism, the raw material for evolution is to acquire enormous genetic diversity under selection pressure providing novel phenotypes. In the genome of almost all flowering plants, genetic and/or epigenetic changes seem to be widespread and lead to apparent impact on biological phenotype, ultimately influencing speciation. Ohno's hypothesis of genome duplication has also confirmed the key role of genomic changes in molecular evolution [1]. However, there are increasing evidences showing considerable and sometimes very rapid morphological changes following speciation as a result of adaptive radiance, as observed majorly in the largest family of flowering plants i.e. Orchidaceae, having bewildering range of flowers with more than 2500 reported species globally.

The genus Dendrobium has been proved a very useful and facile system to study the extent of genomic changes and adaptive radiance [2-6], with nearly 1184 reported species distributed throughout Indian sub-continent [7]. 
The species of genus Dendrobium have adapted to a wide variety of habitats ranging from high altitudes in the Himalayan Mountains to lowland tropical forests, and even to the dry climate of Australian deserts [8]. The orchids of this genus are incredibly prevalent because of their large flashy flowers contributing significantly to floriculture industries. Most of the species of the genus Dendrobium are epiphytic in nature, or occasionally observed to be lithophytic. The principal characteristics of the genus, for example, size, habit, form of stem and leaf, shape, and structure and color of flowers have varied significantly at inter-specific level. The taxonomic placement of this genus is usually based on the floral characters however, the use of important vegetative characters such as stem, leaf, inflorescence, mixed floral and pollinia traits and seed micro- specifics has also been emphasized [3,9-14].

The seeds of orchids are generally microscopic and numerous, in some species over a million per capsule having a simple embryo and often lacking endosperm $[11,15,16]$. The seeds are wind dispersed and exhibit a great deal of varied morphological characters in size, form and structure, for example, seed size varies from $150 \mathrm{~mm}$ to $6000 \mathrm{~mm}$ [17]. The seeds are protected with seed coat often showing marked thickenings and sculpturing. The thickenings are thin in terrestrial orchids whereas thick in epiphytes [18]. The testa cells and embryos of different species may vary significantly in size, shape, colour, and volume [19-21]. The number of cells contributing to testa formation also varies greatly among species, ranging from 2 - 20 in number and most often studied through scanning electron microscopy [17-19].

Changes in seed morphology brought about through evolution had been important as a source of systematic character to circumscribe sub generic groups or hypothetical relationships among species within a genus [2224]. Recent study on different species of Dendrobium has developed precise seed micromorphometric markers for comparative phylogeny of Dendrobium [10]. Hence, the seed characters such as shape, color, length, breadth are significantly important as taxonomic markers and for revelation of phylogenetic relationships among species [10]. However, seed micro-specifics in orchid systematic had restricted exploration as taxonomic and climatic preferences.

Since seed coat ornamentation and sculpturing are considered non-specific to reveal the taxonomic relationship at inter-specific level, comparative knowledge of seed micromorphology in respect to their climatic preferences is yet scarce in orchids [18,25-27]. We hypothesized that such characters may be largely governed or get modulated according to ecological adaptations. Since the general mode of seed dispersal of epiphytic orchid is through air, therefore, it could be expected that seed ultra-structures will be marked or influenced by their distribution pattern at varied altitudes in due course of thousands of years of adaptation. With this hypothesis, in the present study, seed micromorphometric measurements and ultrastructures of second largest and taxonomically complex genus Dendrobium were explored in a comparative account at inter-specific level, and assessed the correlation if such changes had been evolved with ecological adaptations due to altitude based phytogeographical distribution of the respective species.

\section{MATERIAL AND METHODS}

\subsection{Plant Material}

Twenty different species of the genus Dendrobium were collected from defined climatic regions of eastern North India (Figure 1). After collection all samples were duly indentified at Botanical Survey of India for further analyses. The collection for the present study included: $D$. chrysanthum, $D$. chrysotoxum, $D$. clavatum, $D$. crepidatum, D. densiflorum, D. devoninum, D. farmeri, D. fimbriatum, $D$. formosum, $D$. heterocarpum, $D$. hookerianum, $D$. infundibulum, D. moschatum, D. nobile, $D$. ochreatum, D. parishii, D. primulinum, D. transparens, $D$. wardianum, and $D$. williumsonii. The matured seedcapsules were collected from their natural habitat during 2007 to 2010. To reveal intra-specific variations, biological replicates of capsules from 2 - 6 individuals per species were sampled as per the availability. Capsules were subsequently split-opened and the seeds were collected and stored in small-cap vials (Tarson) at $4^{\circ} \mathrm{C}$ in dry conditions.

\subsection{Morphological Analyses}

Wild forms were evaluated for seed characters in the field at the time of collection and/or in the laboratory. Morphological characteristics from all collected species multiple plants per species were recorded using previously reported seed traits descriptors, from which 13 are quantitative variables [28]. These descriptors include characteristics of seed shape, color, length, width, L/W ratio, seed volume, testa call length, testa cell width, testa cell number on long axis, embryo length, width, L/W ratio, volume and percentage free air space (Table 1). States of shape characters were identified according to the plant identification terminology [29]. To analyze statistically each species, we used the mean for each quantitative character.

\subsection{LM Study}

Seeds were stained with safranin and spread on a slide with a drop of water and covered with a cover slip. Twenty seeds were observed for each species and mea- 


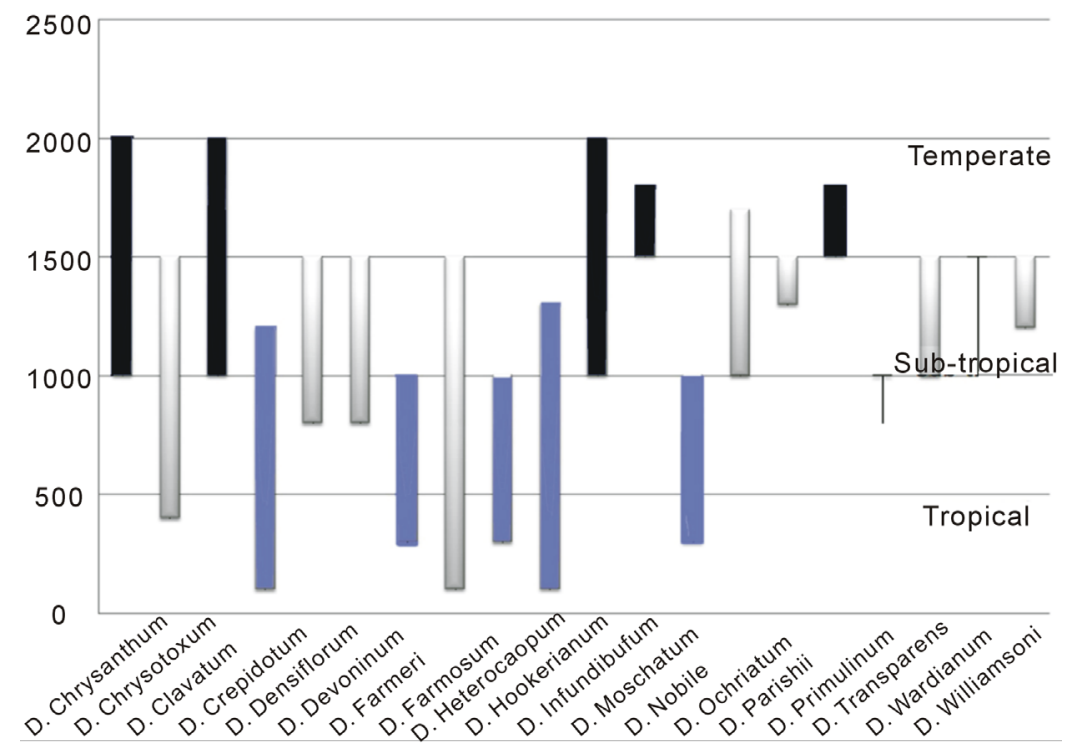

Figure 1. Altitude based distribution of twenty different species of Dendrobium into northern east India.

Table 1. Micromorphometric data of seeds and embryo related characters from species of the genus Dendrobium belonging to different climatic regions. Numerically labeled columns represent different studied seed micromorphometric traits.

\begin{tabular}{|c|c|c|c|c|c|c|c|c|c|c|c|c|c|c|c|c|c|}
\hline \multirow[b]{2}{*}{ SN } & \multirow[b]{2}{*}{ pecies name } & \multirow{2}{*}{$\begin{array}{l}\text { Climatic } \\
\text { region }\end{array}$} & \multirow[b]{2}{*}{ Shape } & \multirow[b]{2}{*}{ Color } & \multirow{2}{*}{$\begin{array}{c}1 \\
\begin{array}{c}\text { SL } \\
(\boldsymbol{\mu m})\end{array}\end{array}$} & \multirow{2}{*}{$\begin{array}{c}2 \\
\begin{array}{c}\text { SW } \\
(\boldsymbol{\mu m})\end{array}\end{array}$} & \multirow{2}{*}{$\begin{array}{c}3 \\
\text { SL/ } \\
\text { SW }\end{array}$} & \multirow{2}{*}{$\begin{array}{c}4 \\
\begin{array}{c}S V \\
\left(\mu^{3}\right)\end{array}\end{array}$} & \multirow{2}{*}{$\begin{array}{c}5 \\
\text { TcL } \\
(\mu \mathrm{m})\end{array}$} & \multirow{2}{*}{$\begin{array}{c}6 \\
\text { TcW } \\
(\mu \mathrm{m})\end{array}$} & \multirow{2}{*}{$\begin{array}{c}7 \\
\text { TcN }\end{array}$} & \multirow{2}{*}{$\begin{array}{c}8 \\
\begin{array}{c}E L \\
(\mu \mathrm{m})\end{array}\end{array}$} & \multirow{2}{*}{$\begin{array}{c}9 \\
\text { EW } \\
(\boldsymbol{\mu m})\end{array}$} & \multirow{2}{*}{$\begin{array}{c}10 \\
\mathbf{E L} / \mathbf{E} \\
\mathbf{W}\end{array}$} & \multirow{2}{*}{$\begin{array}{c}11 \\
\begin{array}{c}\left.E \mathbf{H}^{3}\right) \\
\left(\mathbf{m}^{3}\right)\end{array}\end{array}$} & \multirow{2}{*}{$\begin{array}{c}12 \\
\text { SV/ } \\
\text { EV }\end{array}$} & \multirow{2}{*}{$\begin{array}{c}13 \\
\text { AS } \\
\text { (\%) }\end{array}$} \\
\hline & & & & & & & & & & & & & & & & & \\
\hline 1 & D. chrysanthum & Temperate & & & 4.54 & 0.400 & 11.29 & 0.82 & 3.50 & 0.158 & 7.30 & 0.18 & 0.08 & 2.30 & 0.54 & 1.52 & 35.18 \\
\hline 2 & D. clavatum & Temperate & $\begin{array}{l}\text { Oval and } \\
\text { twisted }\end{array}$ & Yellow & 3.80 & 0.380 & 9.99 & 1.01 & 5.10 & 0.123 & 5.75 & 0.16 & 0.08 & 2.00 & 0.56 & 1.80 & 44.30 \\
\hline 3 & D. hookerianum & Temperate & Fusiform & $\begin{array}{c}\text { Brownish } \\
\text { yellow }\end{array}$ & 4.55 & 0.400 & 11.14 & 0.84 & 3.50 & 0.158 & 7.38 & 0.18 & 0.08 & 2.30 & 0.54 & 1.54 & 35.18 \\
\hline 4 & D. chrys & Sub-tropical & Fusiform & $\begin{array}{l}\text { Orange } \\
\text { yellow }\end{array}$ & 3.14 & 0.350 & 8.77 & 1.21 & 4.60 & 0.106 & 6.50 & 0.19 & 0.10 & 2.00 & 0.93 & 1.30 & 23.26 \\
\hline 5 & D. densiflorum & Sub- tropical & Fusiform & $\begin{array}{l}\text { Orange } \\
\text { yellow }\end{array}$ & 4.26 & 0.340 & 12.40 & 0.58 & - & - & - & 0.16 & 0.07 & 2.20 & 0.42 & 1.38 & 27.59 \\
\hline 6 & D. devonianum & Sub- tropical & Fusiform & Yellow & 5.19 & 0.424 & 12.25 & 0.73 & 3.70 & 0.129 & 7.25 & 0.17 & 0.07 & 2.40 & 0.46 & 1.59 & 36.94 \\
\hline 7 & D. infundibulum & Sub- & Fusiform & White & 5.50 & 0.750 & - & - & - & - & - & 0.26 & 0.15 & - & - & - & - \\
\hline 8 & D. nobile & Sub- tropical & Fusiform & Yellow & 3.50 & 0.405 & 8.66 & 1.41 & 4.70 & 0.122 & 7.88 & 0.17 & 0.11 & 1.60 & 0.99 & 1.43 & 30.08 \\
\hline 9 & D. ochriatum & Sub- tropical & Fusiform & Yellow & 5.43 & 0.726 & 7.49 & 3.38 & 4.70 & 0.139 & 8.75 & 0.26 & 0.12 & 2.10 & 2.13 & 1.59 & 37.23 \\
\hline 10 & D. parishii & Sub- tropical & Fusiform & Yellow & 3.58 & 0.378 & 9.49 & 0.88 & 3.10 & 0.122 & 5.50 & 0.16 & 0.09 & 1.90 & 0.63 & 1.40 & 28.53 \\
\hline 11 & D. transparens & Sub- tropical & Fusiform & Yellow & 5.02 & 0.312 & 16.10 & 0.31 & 5.00 & 0.121 & 4.88 & 0.09 & 0.04 & 2.00 & 0.09 & 3.56 & 71.89 \\
\hline 12 & D. wardianum & Sub- tropical & Fusiform & Yellow & 3.78 & 0.367 & 10.31 & 1.01 & 5.10 & 0.123 & 5.75 & 0.16 & 0.08 & 2.00 & 0.56 & 1.80 & 44.30 \\
\hline 13 & D. williumsonii & Sub- tropical & Elliptic & $\begin{array}{l}\text { Orange } \\
\text { yellow }\end{array}$ & 3.32 & 0.290 & 11.46 & 0.65 & 3.00 & 0.139 & 5.75 & 0.19 & 0.08 & 2.20 & 0.64 & 0.88 & 21.72 \\
\hline 14 & D. crepidatum & Tropical & Fusiform & Yellow & 4.535 & 0.522 & 8.69 & 1.80 & 5.70 & 0.093 & 1.13 & 0.20 & 0.11 & 1.90 & 1.16 & 1.56 & 35.82 \\
\hline 15 & D. farmeri & Tropical & Fusiform & Yellow & 4.481 & 0.388 & 11.55 & 0.81 & 3.60 & 0.122 & 5.10 & 0.20 & 0.07 & 2.85 & 0.65 & 1.25 & 19.63 \\
\hline 16 & D. formosum & Tropical & $\begin{array}{l}\text { Oval and } \\
\text { twisted }\end{array}$ & $\begin{array}{l}\text { Orange } \\
\text { yellow }\end{array}$ & 4.492 & 0.398 & 11.29 & 0.81 & 4.00 & 0.127 & 5.13 & 0.20 & 0.08 & 2.40 & 0.66 & 1.24 & 19.63 \\
\hline 17 & D. fimbriatum & Tropical & Fusiform & Yellow & 3.56 & 0.365 & 9.75 & 1.00 & 3.70 & 0.104 & 4.88 & 0.20 & 0.09 & 2.30 & 0.75 & 1.35 & 25.76 \\
\hline 18 & D. heterocarpum & Tropical & Fusiform & Yellow & 3.853 & 0.301 & 12.80 & 0.47 & 3.80 & 0.095 & 4.13 & 0.15 & 0.07 & 1.60 & 0.40 & 1.20 & 16.72 \\
\hline 18 & D. moschatum & & Fusiform & $\begin{array}{l}\text { Orange } \\
\text { yellow }\end{array}$ & 3.439 & 0.337 & 10.20 & 0.84 & 3.80 & 0.114 & 6.88 & 0.17 & 0.09 & 2.00 & 0.66 & 1.28 & 22.07 \\
\hline 20 & D. primulinum & Tropical & Elliptic & $\begin{array}{l}\text { Golden } \\
\text { yellow }\end{array}$ & 3.087 & 0.318 & 9.71 & 0.88 & 3.10 & 0.122 & 5.50 & 0.16 & 0.09 & 1.90 & 0.63 & 1.4 & 28.53 \\
\hline
\end{tabular}

Abbreviations: SL-seed length; SW- seed width, SV-seed volume; TcL-Testa cell length; TcW-Testa cell width; TcN-Testa cell number in longitudinal axis; EL-Embryo length; EW-Embryo width; EV-Embryo volume; AS-Air space. All values entered in columns are the mean values from biological replicates assessed from different species; and calculated alongwith their respective standard deviations (not shown in table). 


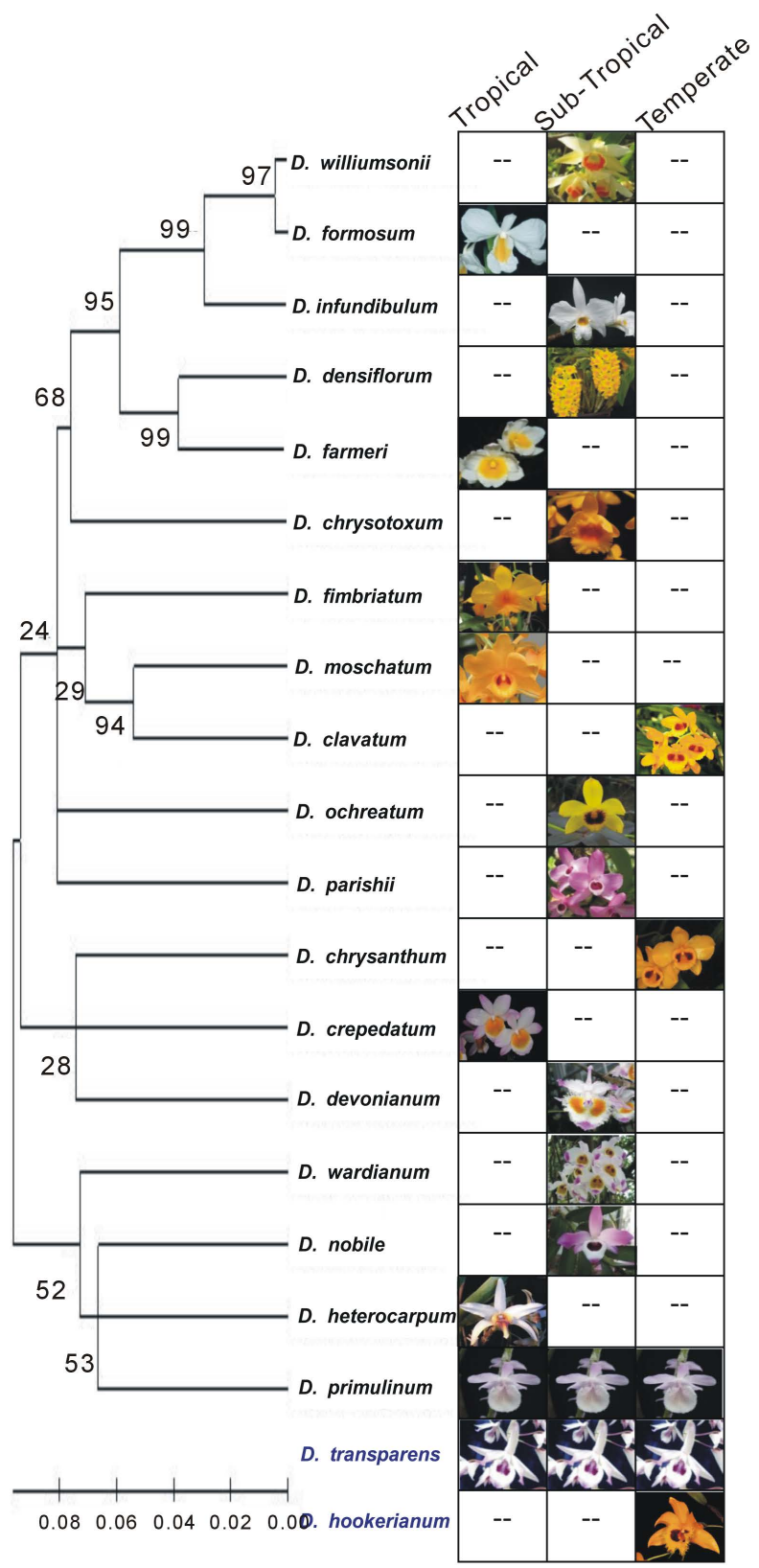

Figure 2. A correlation is shown between DNA based genetic-relatedness among Dendrobium species and their distribution pattern in nature as their prime habitat from eastern North India. The distribution pattern of all twenty different species was confined to a particular geographical region that is tropical, sub-tropical and temperate, except $D$. transparens that showed uniform distribution across climatic regimes. A flower photograph of a species is shown conferring the presence of that species from particular climatic region. Also, a phylogenetic tree derived from rDNA ITS-2 sequences of Dendrobium species (shown at left) revealed the genetic relationship among all twenty species studied except $D$. transparens and $D$. hookerianum where the ITS-2 sequences are not available, and shown at the bottom (marked in blue). Phylogenetically adjacent species exhibited large variation in their distribution patterns ranging from tropical to temperate having subsequent changes in micromorphology may be as a result of ecological adaptations. surements were recorded digitally using Lica DNLP microscope and LicaQueen3 Software. The color of the seeds were observed and described in subjective terms with the help of optical microscope. The following parameters were studied under Light microscope: seedcolor, shape, length, breadth, volume; testa cells- number in longitudional axis, shape, length, breadth; embryolength, breadth, volume; and percentage of free air space present. The seed and embryo volumes were calculated following described method [19].

\subsection{SEM Study}

The seeds were mounted on aluminium copper stubs using double adhesive tape. The samples were then sputter-coated with gold palladium alloy for five minutes and photographed on a JEOL-35 JSMCT-SEM at an accelerating Voltage of 15-20 KV. Detailed seed coat (testa cells) surface studies were conducted by observing under SEM. The considered parameters were seed coat sculpturing and thickenings.

\section{STATISTICAL ANALYSIS}

In the present study seeds were collected from at least 5 pods per population and measurements were taken from 20 seeds per pod. Length and breadth of seed, embryo, and testa cell were measured. Mean values were calculated upto $4^{\text {th }}$ decimal point for each species along with standard error. Correlation analysis had been performed among different seed characters and among species from three altitudinal climatic zone with respect to single seed characters.

\section{RESULTS AND DISCUSSION}

\subsection{Distribution of Dendrobium Species in Eastern North India}

Eastern North India has well-distinguished and characterized altitude based phytogeographical realms [28]. Twenty representative species of the genus Dendrobium were studied covering almost continuous distribution among temperate to tropical and sub-tropical regions (Figure 1). Among the studied species, representatives from tropical region were $D$. crepidatum, $D$. farmeri, $D$. formosum, $D$. fimbriatum, $D$. heterocarpum, $D$. moschatum and $D$. primulinum; representatives from subtropical region were $D$. chrysotoxum, $D$. densiflorum, $D$. devonianum, $D$. infundibulum, $D$. nobile, $D$. ochriatum, $D$. parishii, $D$. transparens, $D$. wardianum and $D$. williumsonii; and representatives from temperate region were $D$. chrysanthum, D. clavatum, D. hookerianum (Figure 2). The studied species were representatives from different classified sections earlier defined based on morphological characters based on a combined list for the Dendro- 
biinae on the Indian subcontinent, including Bhutan, Nepal, Sri Lanka, and Andaman/Nicobar islands [14, 28,30-33].

These sections are 1) Section Densiflora (syn. Callista), included species are D. chrysotoxum, D. densiflorum, D. farmeri, 2) Section Holochrysa, included species are D. hookerianum, D. fimbriatum, D. moschatum, D. clavatum (syn. D. denneanum) 3) Section Dendrobium, included species are D. chrysanthum, D. heterocarpum, $D$. parishii, D. primulinum (D. polyanthum), D. transparens, D. wardianum, D. crepidatum, D. nobile, D. ochreatum, D. devoninum and 4) Section Formosae, included species are $D$. formosum, $D$. infundibulum, $D$. williumsonii).

Collection of different species was focused on the defined geographic regions where populations exhibited typical species characteristics without any disorder. The preference of any species from specific geographic region was also confirmed with reported habitats of Dendrobium species [28]. Selected species such as D. primulinum and $D$. transparens were observed to be uniformly distributed across virtual altitude barriers, though with hyper-variables in seed micromorphology (Figure 1). This observation led to the hypothesis that phylogenetically close species or at times same species got adapted in different climatic regions during their adaptive diversification (Figure 2), and it may be for the reason that any such change would preferentially occur only due to their adaptation according to climatic preferences without having any genomic changes.

\subsection{Variations in Seed Micromorphometric Traits in Dendrobium Species}

Seeds from Dendrobium species are extremely small, being less than $1 \mathrm{~mm}$ in size, with a wide variety of shapes (ellipsoid, oblongoid, ovoid, globose, trigonous or tetragonous) [11,16,17]. The seed coat is reticulated with polygonal cells, which range from more or less isodiametric to tangentially elongated, being sometimes irregular. Dendrobium seeds usually have a smooth membranous outer periclinal wall, although they can sometimes have a fibrillar aspect due to epicuticular waxes. Scanning electron microscopy based observations indicated that there were distinct and recognizable morphological seed types [10]. Thirteen seed micromorphometric variables including seed micromorphology and embryo related characters were examined across all collected species (Table 1 ).

Seeds from Temperate region species: Occurring at 1000 - 2000 meters altitude, seeds are $0.35-0.55 \times 0.08$ $-0 \cdot 11 \mathrm{~mm}$ in size, ellipsoid to ovoid or fusiform in shape; yellow to orange yellow or very dark brown, $0.83-1.6$ $\mathrm{mm}^{3}$ seed volume. Testa cells are $87.8-125.7 \times 10.5-$ $15.8 \mu \mathrm{m}$ in size, seed-coat surface of isodiametric cells. Anticlinal walls with remarkably deep thickening at the vertex, and with a narrow trough marking the wall junctures between cells; outer periclinal walls smooth, impeding vision of the inner one (Figures 3(a),(b)). Embryos $0.16-0.19 \times 0.07-0.10 \mathrm{~mm}$ in size, seed volume by embryo volume $1.54-2.40 \mathrm{~mm}^{3}$, free air space 35.1 - 58.4\% (Table 1). Among the examined species, seeds of $D$. chrysanthum, D. clavatum and D. hookerianum had these seed characteristics.

Seeds from Sub-Tropical region species: Occurring at $800-1500$ meters altitude, seeds are $0 \cdot 31-0 \cdot 35 \times 0 \cdot 06$ $-0.11 \mathrm{~mm}$ in size, ovoid to fusiform in shape, orange yellow, $0.31-1.2 \mathrm{~mm}^{3}$ seed volume. Testa cells are 72.3 $-87.8 \times 10.6-12.1 \mu \mathrm{m}$ in size. Epidermal seed-coat of polygonal \pm isodiametric cells or tangentially elongated $0.06-0.2 \times 0.04-0.10 \mathrm{~mm}$, with anticlinal walls from slightly to remarkably deep, evenly or unevenly thickened, and with a narrow trough marking the wall junctures between cells, sometimes just evident at the vertex; inner periclinal wall perforate (Figures 3(c)-(f)). Embryos are $0.08-0.19 \times 0.04-0.09 \mathrm{~mm}$ in size, seed volume by embryo volume is $1.30-3.55 \mathrm{~mm}^{3}$, free air space $23.2-71.8 \%$ (Table 1 ). Among the examined species, seeds of $D$. parishii, D. williumsonii, D. densiflorum and $D$. nobile had these seed characteristics.

Seeds from Tropical region species: Occurring at 100 -

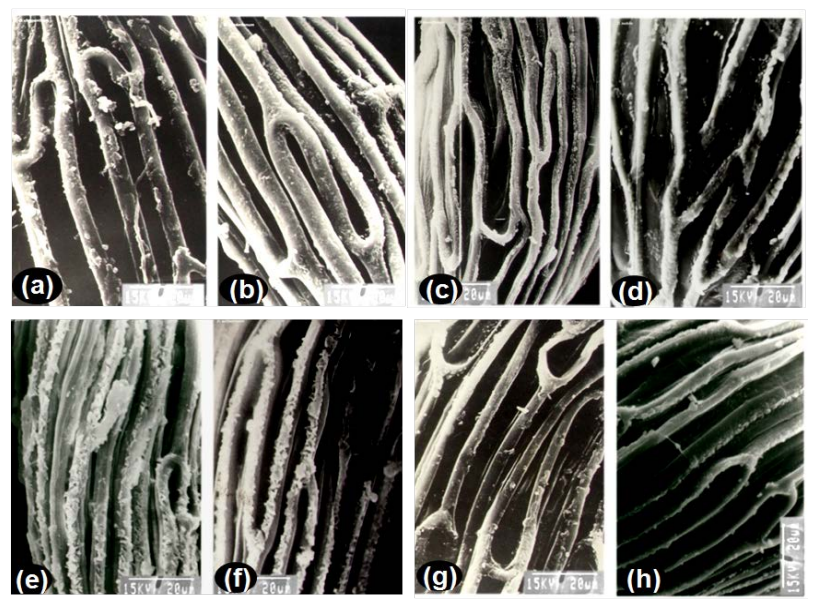

Figure 3. Patterns of testa cell wall thickning in representative species of Dendrobium belonging to different phytogeographical regions. In temperate region species, the wall of the testa cells were smooth without any reticulation as characterized in (a) D. chrysanthum, and (b) D. hookerianum . In sub-tropical region species, the testa cell wall thickenings may be characterized into two types. First, the raised testa walls of some subtropical species such as (c) D. densiflorum, and (d) D. nobile were sculptured with bead-like structures giving an appearance of beads on strings. Second, the testa cell wall thickenings of some subtropical species such as (e) D. parishii, and (f) $D$. williumsonii were also observed to be covered with cottony-white substances as evident in characteristic features of these two species. In tropical region species, the testa cells were raised with or without bead like structure as evident in (g) $D$. crepidatum, and (h) D. farmeri. 
1000 meters altitude, seeds are $0 \cdot 29-0 \cdot 39 \times 0 \cdot 07-0 \cdot 10$ $\mathrm{mm}$ in size, elliptical to ovoid, twisted and fusiform in shape, color orange yellow to golden yellow, $0.47-1.0$ $\mathrm{mm}^{3}$ seed volume. Testa cells $89.0-112.5 \times 9.5-13.9$ $\mu \mathrm{m}$. Epidermal seed coat cells more or less isodiametric to tangentially elongated, anticlinal walls of medium depth and evenly thickened, with a narrow trough that is noticeable all around the edge of the cells or just at the vertices (Figures 3(g),(h)). Embryos are $0.15-0.19 \times$ $0.07-0.09 \mathrm{~mm}$ in size, seed volume by embryo volume $1.20-1.40 \mathrm{~mm}^{3}$, free air space $22.0 \%$ - 28.5\% (Table 1 ). Among the examined species, seeds of $D$. crepidatum, $D$. farmeri, $D$. formosum, $D$. fimbriatum, $D$. heterocarpum, $D$. moschatum and $D$. primulinum had these seed characteristics. Data suggested that seed micromorphometric characters had varied significantly between temperate to sub-topical species whereas less variation was observed in tropical species.

\subsection{Seed Characters Acquired in Response to Climatic Preferences}

Previous observations have clarified that seed quantitative characters such as seed length, seed width, embryo length, embryo width, testa cell length and testa cell width were important to deduce phylogenetic relationship among species of the genus Dendrobium and was comparable to rDNA ITS-2 based phylogeney [10]. Such characters are largely governed by genomic changes or get modulated according to ecological adaptations. To explore the potential of latter, a novel comparative analysis of seed micromorphology and ultrastructure was performed in twenty species of the genus Dendrobium (Orchidaceae) from well-defined altitude based phytogeographical realms i.e. temperate, subtropical and tropical regions (Figure 2). The studied characters included seed volume, free air space, seed coat ornamentation of the periclinal walls and seed coat sculpturing those could easily be used to distinguish groups of species based on defined climatic regions. However, genetic relatedness derived with these characters among all studied species from different geographical regimes showed non-significant correlation $\left(\mathrm{R}^{2}=0.168\right)$ with the phylogeny deduced earlier based on seed quantitative characters (Figure 4) [10]. Based on these results, therefore, it may be concluded that such traits are the direct signatures of adaptation according to climatic preferences rather than their selection during speciation.

\subsubsection{Seed Characters Showing Negative Correlation with Climatic Preferences}

The seed shape and color of mature seed coat of different species of Dendrobium did not exhibit large variations (Table 1). Previously these characters had been considered as distinguishing characters in species identi-

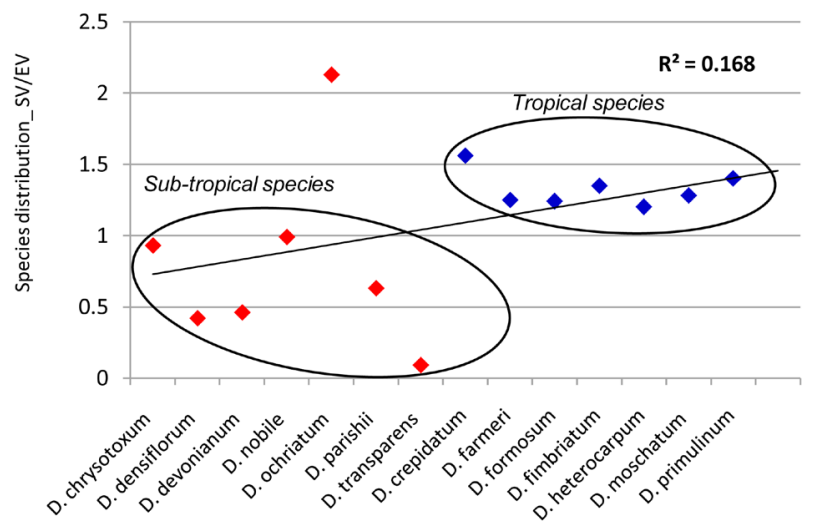

Figure 4. A representative graph drawn based on the ratio of seed volume and embryo volume (SV/EV) showing non-significant correlation between group of different Dendrobium species belonging to tropical and sub-tropical regions. Seed characters such as SV/EV could isolate different phylogenetically related species of genus Dendrobium exhibiting their altitudinal based climatic preferences during speciation.

fication and their subsequent evolution into other morphotypes with adaptive strategy $[10,18]$. However, in the present study no significant contribution of these traits was observed in establishing the positive correlation with different altitude based phytogeographic region of the species. In parallel, seed length/width ratios also exhibited a differential variation among all studied species (Table 2). The patterns of seed growth during maturation suggested that the seed elongated as a result of an elongation in testa cell and not in numbers, thus increases buoyancy of seed beneficial for wind dispersion [20]. Although the relative degree of truncation of the seeds has been utilized as a good taxonomic parameter for species identification, yet it could not distinguish among species from different climatic regions [20]. Therefore, seed length, width and their ratio were also observed to be non-significant in relation to phytogeographical distribution of the species.

\subsubsection{Precise Seed-Specifics and Ultra-Structures Showing Positive Correlation with Climatic Preferences}

Testa cells: These cells had a significant variation in their length as well as in orientations; however, different species could easily be grouped based on different phytogeographical regions irrespective to their genetic relationship. The testa cells in Dendrobium species were observed to be long, sub-quadrate, oblong, sub-elliptical or irregular in outline and fusiform in shape as also shown earlier [18-21]. The testa cells had discrete length and width parameters in species from temperate and sub-tropical regions; however, species from tropical region had overlapping dimensions (Table 1). Their size may also be uniform but often varied within the areas 
Table 2. Correlation among seed micromorphometric traits observed to be important for altitudinal based distribution of Dendrobium species; and is highly correlated among themselves and also significantly distinct from other seed-based traits important for deducing phylogeny [10]. Correlation marked in bold shows the high correlation-coefficient among seed micro-morphological traits highlighting adaptive species-diversification of the genus Dendrobium.

\begin{tabular}{|c|c|c|c|c|c|c|c|c|c|c|c|}
\hline & & SEL & SEW & SEV & EML & EMW & EMV & ROV & TCL & TCW & ASP \\
\hline SEL & $\begin{array}{l}\text { Pearson Correlation } \\
\text { Sig. (2-tailed) } \\
\text { N }\end{array}$ & $\begin{array}{c}1.000 \\
20\end{array}$ & $\begin{array}{c}0.632^{*} \\
0.003 \\
20\end{array}$ & $\begin{array}{c}\mathbf{0 . 9 1 0}^{* * *} \\
0.000 \\
20\end{array}$ & $\begin{array}{c}0.698^{* *} \\
0.000 \\
20\end{array}$ & $\begin{array}{c}0.745^{*} \\
0.000 \\
20\end{array}$ & $\begin{array}{c}\mathbf{0 . 7 5 5}^{* *} \\
0.000 \\
20\end{array}$ & $\begin{array}{c}0.353 \\
0.127 \\
20\end{array}$ & $\begin{array}{c}-0.063 \\
0.792 \\
20\end{array}$ & $\begin{array}{c}0.400 \\
0.081 \\
20\end{array}$ & $\begin{array}{c}0.451^{*} \\
0.046 \\
20\end{array}$ \\
\hline SEW & $\begin{array}{c}\text { Pearson Correlation } \\
\text { Sig. (2-tailed) } \\
\text { N }\end{array}$ & $\begin{array}{c}0.632^{* *} \\
0.003 \\
20\end{array}$ & $\begin{array}{c}1.000 \\
20\end{array}$ & $\begin{array}{c}\mathbf{0 . 8 5 0}^{* *} \\
0.000 \\
20\end{array}$ & $\begin{array}{c}0.664^{*} \\
0.001 \\
20\end{array}$ & $\begin{array}{c}\mathbf{0 . 8 3 4}^{* *} \\
0.000 \\
20\end{array}$ & $\begin{array}{c}\mathbf{0 . 8 3 4}^{* *} \\
0.000 \\
20\end{array}$ & $\begin{array}{c}0.226 \\
0.338 \\
20\end{array}$ & $\begin{array}{c}-0.188 \\
0.427 \\
20\end{array}$ & $\begin{array}{c}0.112 \\
0.639 \\
20\end{array}$ & $\begin{array}{c}-0.092 \\
0.701 \\
20\end{array}$ \\
\hline SEV & $\begin{array}{c}\text { Pearson Correlation } \\
\text { Sig. (2-tailed) } \\
\text { N }\end{array}$ & $\begin{array}{c}\mathbf{0 . 9 1 0}^{* *} \\
0.000 \\
20\end{array}$ & $\begin{array}{c}\mathbf{0 . 8 5 0}^{* *} \\
0.000 \\
20\end{array}$ & $\begin{array}{c}1.000 \\
20\end{array}$ & $\begin{array}{c}\mathbf{0 . 7 3 1}^{* *} \\
0.000 \\
20\end{array}$ & $\begin{array}{c}\mathbf{0 . 8 2 5}^{* *} \\
0.000 \\
20\end{array}$ & $\begin{array}{c}\mathbf{0 . 9 2 1}^{* *} \\
0.000 \\
20\end{array}$ & $\begin{array}{c}0.100 \\
0.676 \\
20\end{array}$ & $\begin{array}{c}-0.071 \\
0.766 \\
20\end{array}$ & $\begin{array}{c}0.272 \\
0.246 \\
20\end{array}$ & $\begin{array}{c}0.216 \\
0.360 \\
20\end{array}$ \\
\hline EML & $\begin{array}{c}\text { Pearson Correlation } \\
\text { Sig. (2-tailed) } \\
\text { N }\end{array}$ & $\begin{array}{c}\mathbf{0 . 6 9 8}^{* *} \\
0.001 \\
20\end{array}$ & $\begin{array}{c}0.664^{*} \\
0.001 \\
20\end{array}$ & $\begin{array}{c}\mathbf{0 . 7 3 1} \\
0.000 \\
20\end{array}$ & $\begin{array}{c}1.000 \\
20\end{array}$ & $\begin{array}{c}\mathbf{0 . 8 6 4}^{* *} \\
0.000 \\
20\end{array}$ & $\begin{array}{c}\mathbf{0 . 8 3 0}^{* *} \\
0.000 \\
20\end{array}$ & $\begin{array}{c}-0.159 \\
0.504 \\
20\end{array}$ & $\begin{array}{c}0.083 \\
0.728 \\
20\end{array}$ & $\begin{array}{c}0.432 \\
0.057 \\
20\end{array}$ & $\begin{array}{c}-0.150 \\
0.527 \\
20\end{array}$ \\
\hline EMW & $\begin{array}{l}\text { Pearson Correlation } \\
\text { Sig. (2-tailed) } \\
\text { N }\end{array}$ & $\begin{array}{c}0.745^{*} \\
0.000 \\
20\end{array}$ & $\begin{array}{c}\mathbf{0 . 8 3 4}^{* *} \\
0.000 \\
20\end{array}$ & $\begin{array}{c}\mathbf{0 . 8 2 5}^{* *} \\
0.000 \\
20\end{array}$ & $\begin{array}{c}\mathbf{0 . 8 6 4}^{* *} \\
0.000 \\
20\end{array}$ & $\begin{array}{c}1.000 \\
20\end{array}$ & $\begin{array}{c}\mathbf{0 . 8 6 6}^{* *} \\
0.000 \\
20\end{array}$ & $\begin{array}{c}-0.008 \\
0.974 \\
20\end{array}$ & $\begin{array}{c}-0.136 \\
0.569 \\
20\end{array}$ & $\begin{array}{c}0.441 \\
0.052 \\
20\end{array}$ & $\begin{array}{c}0.009 \\
0.970 \\
20\end{array}$ \\
\hline EMV & $\begin{array}{c}\text { Pearson Correlation } \\
\text { Sig. (2-tailed) } \\
\text { N }\end{array}$ & $\begin{array}{c}\mathbf{0 . 7 5 5}^{* *} \\
0.000 \\
20\end{array}$ & $\begin{array}{c}\mathbf{0 . 8 3 4}^{* *} \\
0.000 \\
20\end{array}$ & $\begin{array}{c}\mathbf{0 . 9 2 1 * *} \\
\mathbf{0 . 0 0 0} \\
20\end{array}$ & $\begin{array}{l}\mathbf{0 . 8 3 0}^{* *} \\
.000 \\
020\end{array}$ & $\begin{array}{c}\mathbf{0 . 8 6 6}^{* *} \\
0.000 \\
20\end{array}$ & $\begin{array}{c}1.000 \\
20\end{array}$ & $\begin{array}{c}-0.107 \\
0.654 \\
20\end{array}$ & $\begin{array}{c}0.026 \\
0.914 \\
20\end{array}$ & $\begin{array}{c}0.262 \\
0.265 \\
20\end{array}$ & $\begin{array}{c}-0.073 \\
0.760 \\
20\end{array}$ \\
\hline ROV & $\begin{array}{c}\text { Pearson Correlation } \\
\text { Sig. (2-tailed) } \\
\text { N }\end{array}$ & $\begin{array}{c}0.353 \\
0.127 \\
20\end{array}$ & $\begin{array}{c}-0.226 \\
0.338 \\
20\end{array}$ & $\begin{array}{c}0.100 \\
0.676 \\
20\end{array}$ & $\begin{array}{c}-0.159 \\
0.504 \\
20\end{array}$ & $\begin{array}{c}-0.008 \\
0.974 \\
20\end{array}$ & $\begin{array}{c}-0.107 \\
0.654 \\
20\end{array}$ & $\begin{array}{c}1.000 \\
20\end{array}$ & $\begin{array}{c}-0.145 \\
0.541 \\
20\end{array}$ & $\begin{array}{c}0.340 \\
0.143 \\
20\end{array}$ & $\begin{array}{c}\mathbf{0 . 9 2 7}^{\text {** }} \\
0.000 \\
20\end{array}$ \\
\hline TCL & $\begin{array}{c}\text { Pearson Correlation } \\
\text { Sig. (2-tailed) } \\
\text { N }\end{array}$ & $\begin{array}{c}-0.063 \\
0.792 \\
20\end{array}$ & $\begin{array}{c}-0.188 \\
0.427 \\
20\end{array}$ & $\begin{array}{c}-0.071 \\
0.766 \\
20\end{array}$ & $\begin{array}{c}0.083 \\
0.728 \\
20\end{array}$ & $\begin{array}{c}-0.136 \\
0.569 \\
20\end{array}$ & $\begin{array}{c}0.026 \\
0.914 \\
20\end{array}$ & $\begin{array}{c}-0.145 \\
0.541 \\
20\end{array}$ & $\begin{array}{c}1.000 \\
20\end{array}$ & $\begin{array}{c}0.353 \\
0.127 \\
20\end{array}$ & $\begin{array}{c}-0.074 \\
0.756 \\
20\end{array}$ \\
\hline TCW & $\begin{array}{l}\text { Pearson Correlation } \\
\text { Sig. (2-tailed) } \\
\text { N }\end{array}$ & $\begin{array}{c}0.400 \\
0.081 \\
20\end{array}$ & $\begin{array}{c}0.112 \\
0.639 \\
20\end{array}$ & $\begin{array}{c}0.272 \\
0.246 \\
20\end{array}$ & $\begin{array}{c}0.432 \\
0.057 \\
20\end{array}$ & $\begin{array}{c}0.441 \\
0.052 \\
20\end{array}$ & $\begin{array}{c}0.262 \\
0.265 \\
20\end{array}$ & $\begin{array}{c}0.340 \\
0.143 \\
20\end{array}$ & $\begin{array}{c}0.353 \\
0.127 \\
20\end{array}$ & 1.000 & $\begin{array}{c}0.273 \\
0.244 \\
20\end{array}$ \\
\hline ASP & $\begin{array}{c}\text { Pearson Correlation } \\
\text { Sig. (2-tailed) } \\
\text { N }\end{array}$ & $\begin{array}{c}0.451 \\
0.046 \\
20\end{array}$ & $\begin{array}{c}-0.092 \\
0.701 \\
20\end{array}$ & $\begin{array}{c}0.216 \\
0.360 \\
20\end{array}$ & $\begin{array}{c}-0.150 \\
0.527 \\
20\end{array}$ & $\begin{array}{c}0.009 \\
0.970 \\
20\end{array}$ & $\begin{array}{c}-0.073 \\
0.760 \\
20\end{array}$ & $\begin{array}{c}\mathbf{0 . 9 2 7}^{* *} \\
0.000 \\
20\end{array}$ & $\begin{array}{c}-0.074 \\
0.756 \\
20\end{array}$ & $\begin{array}{c}0.273 \\
0.244 \\
20\end{array}$ & 1.000 \\
\hline
\end{tabular}

${ }^{* *}$ Correlation is significant at the 0.01 level (2-tailed); ${ }^{*}$ Correlation is significant at the 0.05 level (2-tailed).

such as the median region and on the chalazal end [17]. The micropylar and the chalazal cells were much shorter and stouter than medial cells which enveloped the embryo in all species. The medial cells were elongated in length and encased the embryos in the seeds. The number of testa cell per seed was examined highest in temperate species and lowest in tropical species with an exception of $D$. transparens which was a sub-tropical species with higher number of testa cells.

Seed volume and embryo volume: Earlier, it had been hypothesized that during speciation any variation in the volume of embryos in orchid seeds is due to their increased length rather than their width [19]. This may be because the orchid seeds are extremely small and thin, having ellipsoid to oblongoid shapes and could only lead to elongated embryo cells. This postulation was even evident from the present investigation measuring seed and embryo volume data representing the fact that species from temperate region had the highest ratio followed by sub-tropical and tropical region species (Table 1); and high correlation was observed between two traits (Table 2). This data though showed incongruence with phylogenetic relationship derived from other numeric seed micromorphometric traits as well as rITS-DNA sequences [10]. Hence, genetically related species had different seed volume/embryo volume ratio highlighting the preference of any particular species for a climatic region as their prime habitat (Table 1, Figure 2). However, as an exception species $D$. transparens was observed to have the lowest embryo volume and lowest seed volume/embryo volume ratio making it most buo- yant among all studied species. This improbability is very prominent as this species is distributed throughout climatic regions as well as in some other parts of the country depicting this adaptive change in buoyancy for optimal seed dispersal.

Free air space: Statistical analyses revealed that variation in percent free air-space in seeds of Dendrobium 
species had a significant variation among all species studied from different climatic regions. Data suggested that species from temperate region had the highest \% free air-space followed by species from sub-tropical and tropical regions (Table 1). Some of the species which grow in the transit climatic zones also showed an overlapping pattern in terms of free air-space (data not shown). It is therefore, assumed that the higher percentage of free air-space would be required in the species from temperate region with relatively low atmospheric pressure that had greater buoyancy for optimal seed dispersal. Highly significant correlation between \% free air-space and seed volume/embryo volume supported the assumption of increased seed buoyancy in temperate region species (Table 2). Thus it was concluded that \% free air-space of the seeds was highly correlated with the distribution of species into different climatic regions.

Seed ultra-structures: The usefulness of micromorphological studies on seeds of Dendrobium for differentiating of taxa has earlier been demonstrated [17]. Characters of epidermal seed coat cells have been proved to be very helpful in this aspect. Ornamentation of the periclinal walls could be used to discriminate selective morphological types. In the present study light and scanning electron microscopy was used to examine the seeds from 20 species of genus Dendrobium. The Dendrobium seeds have elongated, thick medial testa cells with relatively high anticlinal cell wall without an abrupt transition zone. SEM studies revealed that the thickening of testa cells was well developed and strongly raised in all studied species. Moreover, testa cells in selected temperate region species such as $D$. chrysanthum, $D$. hookerianum were rather longitudinally folded (Figure 3(a),(b)). Anticlinal walls frequently appeared to be strongly raised whereas the outer periclinal surface was generally sunken or concave providing a tessellate appearance to the surface of a seed. However, the cell lumens in majority of species were almost obliterated due to extensive development of the cell wall thickenings. These observations revealed the simple form of testa cells arrangements, however, in orchid simpler forms were suggested to be typical to terrestrial taxa, and spiral from epiphytic taxon [18]. The observations from Dendrobium species suggested that the testa cells arrangement may vary significantly within genera irrespective to plant habit.

In temperate species, the testa cell walls were smooth and without reticulations as characterized in D. chrysanthum and $D$. hookerianum from morphological section Dendrobium (Figures 3(a),(b)); and D. clavatum (syn. D. denneanum) from section Holochrysa. Since the members of two different morphological sections were available from this region, therefore, it could indeed be ascertained that such traits are specific to the temperate region species. In sub-tropical species testa cell wall thickenings were most prominent and may be characterized into two morphotypes. First, the raised testa cell walls of species such as D. densiflorum (section Densiflora; syn. Callista), and D. nobile (section Dendrobium) were sculptured with bead-like structures giving an appearance of 'beads on strings' (Figures 3(c),(d)). Second, the testa cell walls in D. parishii (section Dendrobium), and D. williumsonii (section Formosae) were covered with cottony-white substances (Figures 3(e),(f)). Both types of testa cell walls are characteristic features of the concerned species, however, these species are phylogenetically distant species belonging to different morphological sections [28]. These results, therefore, indicated that such characters have been evolved as per the climatic preferences of species rather than during speciation. In tropical region species, the testa cells were raised with or without bead-like structure as characterized in $D$. crepidatum (section Dendrobium) and D. farmeri (section Densiflora) (Figures 3(g),(h)). Interestingly, in a single seed some cells were sculptured with bead-like structures and some cells were without any sculpture, for example, $D$. aphyllum, D. primulinum (syn. D. polyanthum) (section Dendrobium) and $D$. formosum (section Formosae). The anticlinal cell walls may also be sculptured forming ridges, reticulations, perforations or scattered varicosities, and could be fairly consistent within genera or sub-tribe [17]. In the present study, it was also ascertained that structure "beads on strings" is a quite common and interesting feature across morpho-sections of species studied. A gradual transition of this structure through reduction of beads number was observed from tropical region species ( $D$. formosum from section Formosae) to subtropical region species $(D$. infundibulum from section Formosae; and D. transparens, and D. wardianum from section Dendrobium) to temperate region species ( $D$. chrysanthum from section Dendrobium; and D. clavatum and D. hookerianum from section Holochrysa). However it could also be assumed that "beads on strings" structure was originally developed into the sub-tropical region members and gradually become obsolete into tropical and temperate region species. Occasional presence of these beads in $D$. farmeri (temperate region species) and $D$. wardianum (tropical region species) supported this assumption. Since these structures were not restricted within members of any defined section and therefore, could be concluded that such traits are not related to speciation, but evolved according to climatic preferences of a species. These data will provide support to the hypothesis for the adaptation of phylogenetically related species in different climatic regions during their adaptive diversification.

\section{CONCLUSION}

The results of the present study highlight, to certain 
extent, the importance of the morphology of orchid seeds in relation to their ecological adaptations required for the dispersal or to the establishment of new plants. Thus, due to their small size, Dendrobium seeds can be regarded as "dust-seeds" that are mainly dispersed by wind with parasitic or hemiparasitic representatives in the family Orchidaceae. The great distance traversed by the orchid seeds is generally attributed to its light weight and buoyancy due to high percentage of air space. This assumption is well reflected among Dendrobium species where the embryo volume and percentage air space is directly related to the climatic preferences of the species reflected through ultra-structure of the seeds. The lower seed volume and higher percentage of free air space in the temperate species suggested an ecological adaptation for proper dispersal in relatively low atmospheric pressure. The ultra structural features also suggested a gradual expansion towards tropical and temperate regions from the subtropical region. Fusiform tessellate seeds are a characteristic feature of the genus Dendrobium. In temperate species the testa cell walls were smooth and without reticulations; in sub-tropical species testa cell wall thickenings were either with bead-like structures or covered with cottony white substances; whereas in tropical species the testa cell walls ornamentation is not that prominent and may be with or without bead like structure. Therefore it is clear that the seed volume, free air space, and seed coat ornamentation in Dendrobium species are directly related to climatic preference of the species rather than its phylogeny.

\section{ACKNOWLEDGEMENTS}

This work was supported by Council of Scientific and Industrial Research (CSIR), Government of India. We also thank Dr. A. Lokho of Department of Botany, Dr. S. J. Pukhan, Dr. A. Mao, and Dr. T. M. Hennuita of Botanical Survey of India, Dr. U. C. Pradhan, Orchid Research Group, India for their support in identification and collection of plant material.

\section{REFERENCES}

[1] Ohno, S. (1970). Evolution by gene duplication. Springer-Verlag, New York. http://dx.doi.org/10.1007/978-3-642-86659-3

[2] Chase, M.W., Cameron, K.M., Barrett, R.L. and Freudenstein, J.V. (2003) DNA data and Orchidaceae systematics: A new phylogenetic classification. In: Dixon, K. M., Kell, S.P., Barrett, R.L. and Cribb, P.J., Eds., Orchid Conservation, Natural History Publications, Kota Kinabalu, 69-89.

[3] Clements, M. (2003). Molecular phylogenetic systematics of the Dendrobiinae (Orchidaceae), with emphasis on Dendrobium sect. Pedilonum. Telopea, 10, 247-298.

[4] Kamemoto, H., Amore, T. and Kuehnle, A. (1990) Breed- ing Dendrobium orchids in Hawaii. University of Hawaii Press, Honolulu.

[5] Kjellson, G., Rasmussen, F. and Du Puy, D. (1985) Pollination of Dendrobium infundibulum, Cymbidium insigne (Orchidaceae) and Rhododendron lyi (Ericaceae) by Bombus eximius (Apidae) in Thailand: A possible case of floral mimicry. Journal of Tropical Ecology, 1, 289-302. http://dx.doi.org/10.1017/S0266467400000389

[6] Yukawa, T., Ohba, H., Cameron, K. and Chase, M. (1996) Chloroplast DNA phylogeny of subtribe Dendrobiinae (Orchidaceae): Insights from a combined analysis based on rbcL sequences and restriction site variation. Journal of Plant Research, 109, 169-176. http://dx.doi.org/10.1007/BF02344542

[7] Leitch, I., Kahandawala, I., Suda, J., Hanson, L., Ingrouille, M., Chase, M. and Fay, M. (2009) Genome size diversity in orchids: Consequences and evolution. Annals of Botany, 104, 469-481. http://dx.doi.org/10.1093/aob/mcp003

[8] Baker, M. and Baker, C. (1996) Orchid Species Culture: Dendrobium. Timber Press Inc., Portland.

[9] Chase, M. (1999) Molecular systematics, parsimony, and orchid classification. In: Pridgeon, A.M., Cribb, P.J., Chase, M.W. and Rasmussen, F.N., Eds., Genera Orchidacearum, General Introduction, Apostasioideae, Cypripedioideae, Oxford University Press, Oxford, 81-88.

[10] Chattopadhyay, P., Banerjee, N. and Chaudhary, B. (2010) Precise seed micromorphometric markers as a tool for comparative phylogeny of Dendrobium (Orchidaceae). Floriculture and Ornamental Biotechnology, 4, 36-44.

[11] Dressler, R. (1993) Phylogeny and classification of the orchid family. Dioscorides Press, Portland.

[12] Hooker, J. (1890) Dendrobium. Flora of British India, 5, 710-752 (suplements, additions, and corrections).

[13] Rasmussen, F. (1999) The development of orchid classification. In: Pridgeon, A.M., Cribb, P.J., Chase, M.W. and Rasmussen, F.N., Eds., Genera Orchidacearum, General Introduction, Apostasioideae, Cypripedioideae, Oxford University Press, Oxford, 3-12.

[14] Wood, H. (2006) The Dendrobiums, A.R.G. Ganter Verlag, Ruggell/Liechtenstein.

[15] Clements, M. (1999) Embryology. In: Pridgeon, A.M., Cribb, P.J., Chase, M.W. and Rasmussen, F.N. Eds., Genera Orchidacearum, Genera Orchidacearum, General Introduction, Apostasioideae, Cypripedioideae, Oxford University Press, Oxford, 38-55.

[16] Molvary, M. and Chase, M. (1999) Seed morphology. In: Pridgeon, A.M., Cribb, P.J., Chase, M.W. and Rasmussen, F.N., Eds., Genera Orchidacearum, Genera Orchidacearum, General Introduction, Apostasioideae, Cypripedioideae, Oxford University Press, Oxford, 59-66.

[17] Molvray, M. and Kores, P. (1995) Character analysis of the seed coat in Spiranthoideae and Orchidoideae, with special reference to the Diurideae (Orchidaceae). American Journal of Botany, 82, 1443-1454. http://dx.doi.org/10.2307/2445872

[18] Vij, S., Kaur, P., Kaur, S. and Kaushal, P. (1992) The orchid seeds: Taxonomic, evolutionary and functional 
aspects. Journal of Orchid Society of India, 6, 91-107.

[19] Arditti, J., Michaud, J. and Healey, P. (1979). Morphometry of orchid seeds. I. Paphiopedilum and native California and related species of Cypripedium. American Journal of Botany, 66, 1128-1137. http://dx.doi.org/10.2307/2442211

[20] Arditti, J., Michaud, J. and Healey, P. (1980) Morphometry of orchid seeds. II. Native California and related species of Calypso, Cephalanthera, Corallorhiza and Epipactis. American Journal of Botany, 67, 347-360. http://dx.doi.org/10.2307/2442345

[21] Swamy, K., Kumar, H., Ramakrishna, T. and Ramaswamy, S. (2004) Studies on seed morphometry of epiphytic orchids from Western Ghats of Karnataka. Taiwania, 4, 124140.

[22] Larry, H. (1995) Seed morphology of Hydrangeaceae and its phylogenetic implications. International Journal of Plant Science, 156, 555-580. http://dx.doi.org/10.1086/297279

[23] Mathews, J. and Levins, P. (1986) The systematic significance of seed morphology in Portulaca (Portulacaceae) under scanning electron microscopy. Systematic Botany, 11, 302-308. http://dx.doi.org/10.2307/2419120

[24] Ness, B. (1989) Seed morphology and taxonomic relationships in Calochotus (Liliaceae). Systematic Botany, 14, 495-505. http://dx.doi.org/10.2307/2418993
[25] Jeeja, G. and Ansari, R. (1994). Taxonomic significance of seed surface morphology in Orchidaceae. Indian Association of Angiospermic Taxonomy, 4, 48-59.

[26] John, R. and Jack, K. (1998) Orchids. 3rd Edition, Sunset Books, Sunset Publishing Corp., Menlo Park, 11-101.

[27] Lumga, M., Cozzolino, S. and Kocyan, A. (2006) Exine micromorphology of Orchidinae (Orchidoideae, Orchidaceae): Phylogenetic constrain or ecological influence? Annals of Botany, 98, 237-244. http://dx.doi.org/10.2307/2418993

[28] Pradhan, U. (1979) Indian orchids: Guide to identification and culture. Vol. 2, Pradhan, Kalimpong.

[29] Harris, J. and Harris, M. (2001) Plant Identification terminology: An illustrated glossary. Spring Lake Publication, Payson.

[30] Bose, S., Bhattacharjee, S., Das, P. and Basak, U. (1999) Orchids of India. Naya Prokash, Calcutta.

[31] Chowdhery, H. (1998) Orchid flora of Arunachal Pradesh. Bisen Singh Mahendra Pal Singh, Dehradun

[32] Pearce, N. and Cribb, P. (2002). The orchids of Bhutan. Royal Botanic Gardens and Royal Government of Bhutan, Edinburgh

[33] Roberts, J., Allman, L., Bealr, C., Butter, R., Crook, K. and McGough, H. (1997). CITES Orchid checklist. Royal Botanic Gardens, Kew England. 